\title{
Irrigating Wastewater using RWIS for Treating in Soil-Plant System
}

\author{
Dahn Rosenquist \\ Rosenquist Mekaniska Verkstad AB, Sweden
}

\begin{abstract}
In Sweden, large areas of willow plantations designated for energy purposes have been established. Pilot tests, using various waste products from society for fertilisation and/or irrigating purposes, have been carried out at Kågeröds wastewater plant since 1992. These tests have clearly shown that recycling of municipal wastewater in Salix plantations, can replace a large part of the conventional wastewater treatment, due to natural purification processes in the soil/plant system. During the last few years, several full-scale treatment plants based on the soil/plant system have been set up. Rosenqvist Mek.Verkstad has developed the irrigation system "RWIS" for distribution of wastewater into the plantation. The system uses a controlled flooding technique, combined with computer operation controlled electric valves placed in the fields. By measuring the flow and having knowledge about the contents of the wastewater, it is possible to have total control over the wastewater that is distributed in a specific area. The irrigation system has to be able to withstand trying conditions, without major maintenance in between harvests.
\end{abstract}

\section{Introduction}

Special conditions apply to irrigation design for wastewater. This requires a system that satisfies the following conditions:

- Potential aerosol leakage must be eliminated.

- Harvesters must be able to move freely, without the system being dismantled

- Low running costs

- Low maintenance costs

- Can be integrated with other water/sewerage systems

RWIS is a concept based on root zone watering. The technology is a type of controlled flooding, combined with broad irrigation. 


\section{Process}

From the treatment plant the sewage is pumped through an underground duct to the Salix field. The duct, which can supply one or more fields with sewage at the same time, is connected to a trunk pipe under the Salix field. Electrically operated valves, one for each module, are mounted on the trunk pipe. The module comprises a trunk pipe (underground) with. on either side, 12 supply pipes with drilled holes (an arrangement similar to the veins in a leaf). The supply pipes lie on the soil surface. Allowing the sewage to flow out at ground level, minimises odour and sanitary problems, and avoids the formation of aerosol. By utilising the horizontal transport of water by the soil and by Dam flooding to exploit undulations of the terrain. the distances between the supply pipes can be made relatively large. Salix have long roots $(10$ metres or more) and Principe schema RWIS

will seek out water and nutrients. Experiments in Kågeröd and Bromölla show that the effect on the groundwater is minimal.

\section{Irrigation amounts}

The Kågeröd experiments indicate that an appropriate sewage irrigation rate is about $6 \mathrm{~mm} /$ day, which gives the heights biomass production. Rates up to $12 \mathrm{~mm} /$ day have been tested. The reduction of total $\mathrm{N}$ was $82-93 \%$ e, $90-97 \%$ of total P and $74-82 \%$ of BOD. The irrigation should follow the vegetative period of the Salix. Normally, the vegetative period begins in May and ends in September-October, depending on the location in Sweden. Especially towards the end of the period, the nitrogen content should be reduced to avoid frost damage. When designing a RWIS, you must consider what is add with the sewage and removed with in the harvest, to maintain the balance of nutritional requirement.

During the non-vegetative period, the sewage is held in ponds or treated in a conventional treatment plant. Calculations show that, even with the costs of holding ponds, the plant based sewage treatment method can compete with conventional treatment technology.

\section{Control system}

The combination of simple equipment and advanced computer-controlled irrigation gives: 
- Optimal growth with maximum nutrient absorption

- Minimal running costs

- Minimal maintenance costs

- Documentation and follow-up

When distributing sewage, it is essential to know where the water goes! This makes demands on the irrigation technology. Using a control system, which takes into account, topography, soil type, sewage quality and external precipitation solves the problem. Infiormation for reporting to authorities is saved and compiled in the system.

There is also an advanced function monitoring system, which minimises the need for maintenance. The control system can be a self-contained unit, or be integrated with the central water/sewage control system.

\section{List of References}

Aronsson, P. \& Perttu, K (Eds.). 1994. Willow vegetation filters for municipal wastewaters and sludges - A biological purification system. Proceedings of a study tour , conference and workshop in Sweden, 5-10 June 1994. Swed. Univ. Agric. Sci., Dept. Short Rotation Forestry, Uppsala. Rep. 50, 230 pp.

Aronsson, P. \& Perttu, K. 1994. A complete system for wastewater treatment using vegetation filters. In: Aronsson, P. \& Perttu, K (Eds.). Willow vegetation filters for municipal wastewaters and sludges - A biological purification system. Proceedings of a study toure, conference and workshop in Sweden, 5-10 June 1994, pp. 211-213.

Bergkvist P. \&, Slam i energiskog (Sludge in energy forest), Agricultural University of Sweden, Fakta-Mark/växt, no. 5, 1995

Perttu, K. \& Koppel, A. (Eds.). 1996. Short rotation willow coppice for renewable energy and improved environment. Proceedings of a joint Swedish-Estonian seminar on on Energy forestry and vegetation filters held in Tartu 24-26 September 1995. Swed. Univ. Agric. Sci., Dept. Short Rotation Forestry; Uppsala. Rep. 57, 172 pp.

Perttu K.L., 1994, Vegetationsfilter av salix renar vatten and mark (Salix vegetation filters clean up water and soil). Agricultural University of Sweden, Skogsfakta no. 9, 1994.

Hasselgren K., 1999, Bevattning av energiskog med förbehandlat avloppsvatten Rapport V A-Forsk 1999-5

Hasselgren K., 1998, Bevattning av energiskog med biologiskt behandlat avloppsvatten Slutrapport till stiftelsen Lantbruksforskning, Projekt 957837

Hasselgren K., 1994, Kommunalt avloppsvatten - en resurs i energiskogsodling (Public sewage - a resource in energy forest cultivation)

Cirkulation 3(5): 6-8 Svalöv

Rosenqvist D., 1998e, RWIS Rosenqvist Wastewater Irrigation System Folder, Rosenqvist Mekaniska Verkstad AB

Rosenqvist, H., Aronsson, P., Hasselgren, K. \& Perttu, K. 1997. Economics of using municipal wastewater irrigation of willow coppice crops. Biomass and Bioenergy, Vol.el 2,eNo.el :1-8.

Stenström, T A. 1996. Sjukdomsframkallande mikroorganismer i avloppssystem. Riskvärdering av traditionella och alternativa avloppslösningar. SNV Rapport 4683. 